\title{
Ehlers-Danlos Syndrome, Type IV
}

National Cancer Institute

\section{Source}

National Cancer Institute. Ehlers-Danlos Syndrome, Type IV. NCI Thesaurus. Code C125699.

Ehlers-Danlos syndrome, type IV is the vascular type Ehlers-Danlos syndrome. It results from mutations in the COL3A1 gene. 